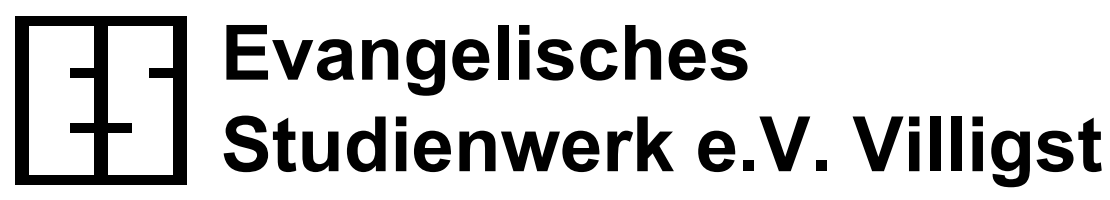
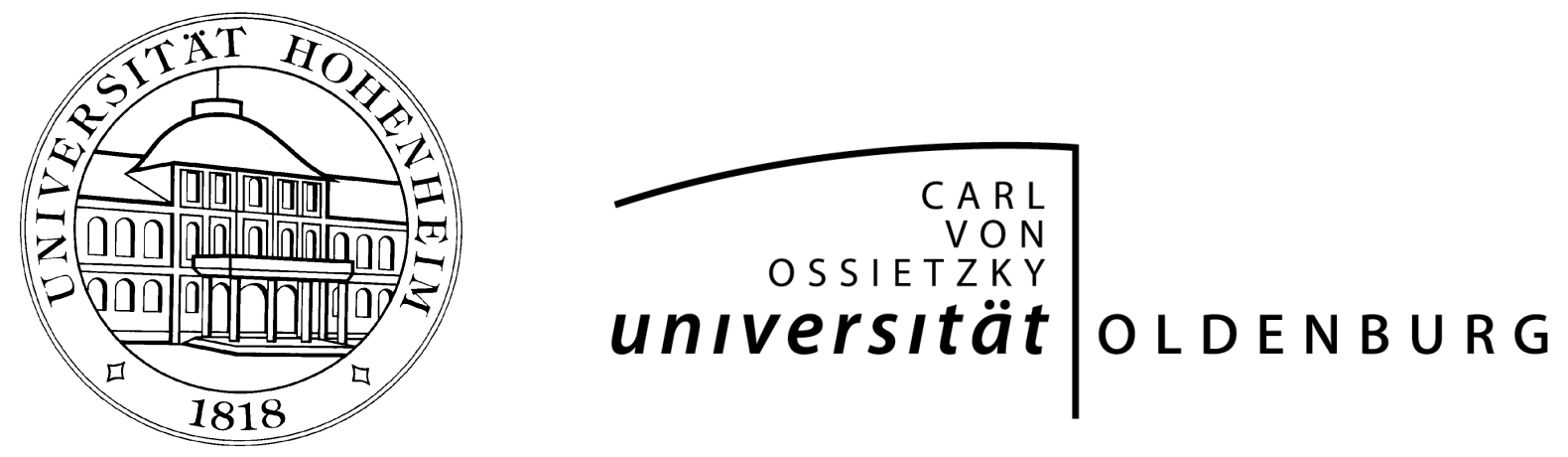

Schriftenreihe des Promotionsschwerpunkts

Globalisierung und Beschäftigung

Nr. 51/2016

Monopsony and Industrial Development in Nineteenth Century Quebec: The Impact of Seigneurial Tenure

Alex Arsenault Morin, Vincent Geloso, Vadim Kufenko

Stuttgart-Hohenheim

ISSN 1618-5358 
Unemployment is persistently high in many European countries. It is frequently attributed to 'functional deficiencies of labor markets', even though to a large extent caused by demand and supply shifts in goods markets and financial markets. The $\mathrm{PhD}$ program Globalization and Employment therefore focuses on the employment effects of structural change and macroeconomic developments and encourages research by granting scholarships. The dissertation projects address topics such as new technologies, processes of internationalization and system transformation, endogenous finance constraints and various strategies of fiscal and monetary policy.

Work and supervision in the $\mathrm{PhD}$ program follows the structures of a standard graduate school. Coordinators and editors of the discussion paper series are the following professors:

Prof. Dr. Harald Hagemann

Department of Economics (520H)

University of Hohenheim

D-70593 Stuttgart

Prof. Dr. Heinz-Peter Spahn

Department of Economics (520A)

University of Hohenheim

D-70593 Stuttgart

Prof. Dr. Hans-Michael Trautwein

Department of Economics and Statistics

Carl von Ossietzky University Oldenburg

D-26111 Oldenburg harald.hagemann@uni-hohenheim.de

peter.spahn@uni-hohenheim.de

michael.trautwein@uni-oldenburg.de

$\mathrm{PhD}$ projects in the program can be funded by grants of the Evangelisches Studienwerk e.V. Villigst. Application forms can be ordered from:

Evangelisches Studienwerk e.V.

Promotionsförderung

Iserlohner Str. 25

D-58239 Schwerte

Phone: +49 (2304) 755-215, Fax: +49 (2304) 755-250

For further information about the $\mathrm{PhD}$ program Globalization and Employment as well as the PDF-files of the discussion papers see:

http://www.globalization-and-employment.de 


\title{
Monopsony and Industrial Development in Nineteenth Century Quebec: The Impact of Seigneurial Tenure
}

\author{
Alex Arsenault Morin, Vincent Geloso, Vadim Kufenko
}

September 22, 2016

\begin{abstract}
We argue that the system of seigneurial tenure used in the province of Quebec until the mid-nineteenth centurya system which allowed significant market power in the establishment of plants, factories and mills, combined with restrictions on the mobility of the labor force within each seigneurial estateis best understood as a system of regionalized monopsonies in the non-farm sector. Seigneurs had incentives to reduce their employment in those sectors to reduce wage rates. We use the fact that later, with the Constitutional Act of 1791, all new settled lands had to be settled under a different system (British land laws). This natural experiment allows us to test our hypothesis that seigneurial tenure was a monopsony, using data from the 1831 and 1851 Lower Canada censuses. We find strong evidence that this difference in tenure partially explains the gap in industrial development between Quebec and the neighboring colony of Ontario.
\end{abstract}

Keywords: Canadian Economic History, Monopsony, Economic development

JEL classification: N11, J42, R52 


\section{Introduction}

In Canadian economic history, the relative poverty of the French-speaking province of Quebec has been a long-lasting puzzle. This relative poverty seems to have started early in the nineteenth century (Inwood and Irwin, 1993, 2002; Arsenault Morin et al., 2016; Green, 1969; McInnis, 1992; Russell, 2012), but the causes are elusive. For the initiation of the gap between Quebec and the rest of Canada, some look as far back as the initial settlement of Quebec and have blamed seigneurial tenurethe provinces unique land tenure system (Jones, 1942, 1946; Phillips, 1974; Altman, 1983, 1987; Armstrong, 1984a). This system of land tenure imposed de jure and de facto restrictions on mobility, imposed substantial taxes that did not go toward the production of public goods, imposed taxes on capital asset transfers, and created legal monopolies on the establishment of mills and other activities. The traditional historiography considered these features as detrimental to growth and development. However, many scholars question this explanation arguing that the role of seigneurial tenure was either minimal (Percy and Szostak, 1992; Courville, 2008) or negligible (Russell, 2012). While seigneurial tenure was abolished in 1854, the general belief is that seigneurial tenure did not initiate Quebec's relative poverty. In this paper, we argue that the role of seigneurial tenure should be reconsidered. Whereas in the past literature seigneurial tenure was often considered as a system of monopolies, this view was limited to the consideration of the goods markets. In the reality, the implications of seigneurial tenure are piercing through other markets, e.g., the labour market. We believe that its effects are best understood if seigneurial tenure is presented under a monopsony model. There are three reasons for this proposition. Firstly, by virtue of the de jure and de facto constraints imposed by the system, mobility was greatly reduced - which is a crucial condition for monopsonies. Secondly, the landlords (seigneurs) had monopoly rights on numerous types of mills and factories. In addition, the types of mills and factories that were not subject to monopoly right could be taxed by the seigneur. This conferred disproportionate market power and meant that, in many instances, the seigneur was the sole demander of labor in the non-farm sector. Thirdly, significant population growth until the end of the system in 1854 would have meant a substantial increase in the supply of workers while the institutional framework incentivized restraint of demand for labor in the non-farm sector.

That monoposonies have perverse effects on economic development is not a novel argument (Bardhan, 1984). In China, the barriers to mobility generated important gaps in rural areas between the marginal product of labor and wages paid (and also relative to returns to human capital) (Fleisher and Wang, 2004, p. 319), a finding echoed in Dong and Putterman $(2000,2002)$. Theoretically, lower wages than equilibrium in a monopsony discourage the accumulation of human capital which leads to slower economic growth (Barr and Roy, 2008). The existence of monopsony is largely predicated on barriers to mobility. Could the same mechanisms have been at play within Canada as a result of seigneurial tenure?

To test this hypothesis in the Canadian context, we rely on the Constitutional Act of 1791 as a natural experiment. Upon the conquest of the colony in 1760 by the British, the seigneurial system was maintained. However, in the Constitutional Act of 1791, it was frozen to the areas where it had already been conceded - it could not expand. All new settled lands after 1791 had to be settled under British freehold tenure. Until 1854, the two legal systems cohabited side-by-side. With the use of the data from the 1831 and 1851 censuses of Quebec, we differentiate seigneurial areas from non-seigneurial areas in order to test our monopsony line of reasoning. These two censuses contain considerable 
information on the number of plants, factories, mills and foundries established in the colony. These variables allow us to approximate the non-farm demand for labor. The census of 1831 has the added bonus of containing data about local wages and prices from which we can measure living standards.

In both censuses, seigneurial tenure considerably reduced the number of plants, mills, foundries and factories per 1,000 inhabitants relative to non-seigneurial areas - even if the areas where it operated had been settled for longer periods of time and were closer to urban markets. These differences hold even after we control for environmental effects and distance from urban markets. In fact, these differences grow with controls. With the 1831 census for which we have wages, we show that non-seigneurial areas have significantly higher wages than seigneurial areas (controlling for other factors). We use border effects to capture the importance of our monopsony model. We argue that the monopsony power would be greater in seigneuries surrounded only by other seigneuries than it would be in seigneuries that have non-seigneurial neighbours. We find that the greater the level of monopsony power, the lower wages are. We also argue that our results are conservative since we can only measure the effects of seigneurial tenure on the wage rate, not the effects on the level of employment in the non-farm sector. The total welfare loss would have to consider the lower wage rate times the lower levels of employment caused by tenure. This makes our argument quite robust.

\section{Quebec's retarded development and seigneurial tenure}

According to Inwood and Irwin (2002), Quebec's per capita income stood at $87 \%$ of the level observed in Ontario (Canada's richest province) in 1870. While this ratio fell progressively until the 1940s (Green, 1969; Egnal, 1996; Altman, 2003), Quebec's relative poverty was well established by the start of confederation. For the 1850s, McInnis (1992) estimated that net farm income per capita in Quebec was $32 \%$ lower than in Ontario. Recent evidence of grain-wages and welfare ratios in 1831 in Lower Canada (the name of Quebec at the time) compiled by Geloso et al. (2016) confirm that these differences were present early in the nineteenth century. These differences also materialized along biological lines. Cranfield and Inwood (2007, p. 207) found that between 1825 and 1840, Quebec prisoners at the Kingston penitentiary were shorter by one and a half inches while Arsenault Morin et al. (2016) found larger differences between British-born settlers in Canada and French-Canadians as far back as the late eighteenth century. The use of the 1851 census of the different portions of Canada shows that industrial development - as captured by plants, factories and mills relative to population - is much less advanced in Quebec than elsewhere (see Table 1). This relative poverty is not disputed, but its causes are subject to debate.

Quebec's retarded development has been sometimes blamed on cultural peculiarities of French-Canadian society (Ouellet, 1966; Bouchard, 1996), but such explanations have often been brushed aside when made for other societies (see notably Dennison, 2011; Ogilvie, 2001; Ogilvie and Carus, 2014). These explanations have also been largely criticized in Quebec (Lewis and McInnis, 1980, 1984; Armstrong, 1984b,a; Altman, 1998; Arsenault Morin et al., 2015). However, they remain popular because the institutional counter-proposition has been weak. While the traditional literature laid blame at the feet of the institution of seigneurial tenure, a new literature has emerged that argues that this institution had little to no effect. This new literature can be considered as the dominant viewpoint (for an illustration see Grenier, 2012).

Under seigneurial tenure, a landlord (seigneur) who obtained or bought an estate 
Table 1: Industries per 1,000 in the different colonies of Canada, 1851

\begin{tabular}{ccccc}
\hline & $\begin{array}{c}\text { Lower Canada } \\
(\text { Quebec })\end{array}$ & $\begin{array}{c}\text { Upper Canada } \\
\text { (Ontario) }\end{array}$ & New Brunswick & Nova Scotia \\
\hline Grist Mills & 0.61 & 0.73 & 1.35 & 1.44 \\
Saw Mills & 1.2 & 1.65 & 3.01 & 4.16 \\
Textiles Plants & 0.24 & 0.23 & 0.27 & 0.29 \\
Distilleries & 0.01 & 0.11 & - & - \\
Tanneries & 0.23 & 0.23 & 0.64 & 0.86 \\
Breweries & 0.01 & 0.05 & 0.04 & 0.06 \\
Foundries & 0.04 & 0.1 & 0.06 & 0.03 \\
Others & 0.31 & 0.45 & 0.49 & 0.51 \\
\hline Total & $\mathbf{2 . 6 4}$ & $\mathbf{3 . 5 5}$ & $\mathbf{5 . 8 6}$ & $\mathbf{7 . 3 5}$ \\
\hline & Source: Public Archives of Canada $(1876)$ &
\end{tabular}

(seigneurie) had to concede land freely to peasants (censitaires). The censitaires would have to meet several obligations in order to occupy the land. First, they would pay the cens et rentes which were relatively light duties determined by the amount of land held rather than the amount of land actually farmed ${ }^{1}$. Once established, the censitaire had a de jure obligation not to leave his land. This de jure obligation was combined with a de facto limitation on his mobility in the form of the lods et ventes which was a tax on the mutation of land assets. A censitaire had to give his seigneur $8.5 \%$ of the proceeds of the sale of his land. This tax would have acted as a limitation on mobility. The censitaire also had to provide two to three days of per year in exchange as corvée to the seigneur or pay a certain amount for each day not worked (at a rate two to three times the average daily wage rate for unskilled workers). Compounded with these burdens were ancillary taxes which depended on a seigneuries particular features (for example fishing duties or taxes for accessing common pastoral grounds). For his part, the seigneur had to provide milling services at the fixed price of one fourteenth of all grains brought to the mill (Grenier, 2012). Finally, the seigneur had monopoly rights over the establishment of mills and access to waterways. Peasants were not allowed to use grist mills in neighbouring seigneuries, even if those were physically more accessible to them. Moreover, the seigneur had the right to tax everyone on his estate, which acted as a tax on opening plants and factories not operated by the seigneur himself. In the face of economic theory, it is hard to see how restrictions on mobility, taxes on assets and monopoly rights could have favored economic growth. This has been the foundation of the traditional argument. That this system did not exist in areas settled after 1791 (something that we will discuss later in this paper) allows comparisons that suggest differences in living standards caused by institutions. Such differences are well recognized by contemporary observers, who noticed that wages in Lower Canada tended to be below those in Upper Canada "except in the Eastern Townships ("settled under freehold tenure", see Martin, 1838, p. 335). In a Quebec Mercury article (Quebec Mercury, 1831, p. 592), the same observation was related and argued that wages also commanded more purchasing power in non-seigneurial areas. Arsenault Morin et al. (2015) were the first to attempt a wide cross-sectional measurement of differences in living standards by using the infant mortality data in the 1851 census. They uncovered that the seigneurial areas had infant mortality rates roughly twice as high as non-seigneurial areas. After controlling for environmental factors, distance

\footnotetext{
${ }^{1}$ Thus, they should be construed as taxes on capital assets rather than taxes on output.
} 
from urban markets, grain yields and even the ethnic makeup of the local population, the differential remained. Others like Harris (2012, p. 275) also observed that industrial activity - in spite of being far removed from the port cities of Montreal and Quebec - was more intense than in seigneurial areas. However, this has not been sufficiently convincing to skeptics. Altman (1998) computed net farm income in Quebec in 1851 and argued that seigneurial tenure did not explain the differences between French and English areas - even if he was skeptical of the cultural explanation. Altman proposed that access to urban markets would have been the dominant factor. Percy and Szostak (1992, p. 56), who studied the abolition of seigneurial tenure in 1854, stated that "the negative effects of seigneurial tenure on the economy appear to have been exaggerated." To make this claim, they relied on a paper by Lewis and McInnis (1980) showing very small differences in total factor productivities across ethnic lines with the census of 1851, which Percy and Szostak (1992) assume extend along institutional lines. A recent summary provided by Peter Russell confirms the predominance of the viewpoint stating that seigneurial tenure could not have mattered much. In responding to the categorization of seigneurial tenure as creating unfree labor markets, Russell (2012, p. 83) argued that "peasants would have laughed at the notion that they were unfree labor." Russell added that the "contention that 'an abundance of cheap and free land relative to labor encourages unfree (...) labor institutions' is itself laughable". However, we believe this to be a dubious claim for two reasons. First of all, the work of Lewis and McInnis (1980) on which Percy and Szostak (1992) rely shows non-negligible differences: there is gap ranging from a $7.6 \%$ disadvantage to a $15.7 \%$ disadvantage over all regions in terms of TFP. There are also massive differences in partial factor productivity (where labor productivity was much lower in French areas than English areas). Robert Armstrong (1984b) pointed out that Lewis and McInnis (1980) had used prices that were equal throughout the colonya fact that would have eclipsed some of the large price variations between regions due to geographic distance from key urban markets. This would have artificially boosted the value of farm output in French areas.

The second reason is that the literature mostly concentrates on agriculture, which invites a more detailed examination of non-farm activities. While Lower Canada was a predominantly agrarian society, farming was not the sole source of income. The 1831 census inquired about the "number of families earning their subsistence by agricultural employments" and placed that figure at 50,824 families. Given that there were 82,437 houses enumerated in the census, that places the agricultural population at slightly above $61 \%$ of the total population House of Assembly of Lower Canada (1832, App.O.o) While that proportion may seem low, it is not far out of line with the estimate of the population living in villages and cities. At the end of the eighteenth century and especially after 1815 , villages began to appear throughout the colony. By 1851, there were 306 villages in the seigneurial portions of Lower Canada up from 210 in 1831 and 53 in 1815 (Courville, 1990, p. 34) . Labelling the rise of these villages as "proto-urbanization" (Courville, 1990, p. 239) is appropriate as they constituted the cores of future towns and contained numerous light industries. Taken alone, the cities and towns saw their share of total population grow from $11.04 \%$ to $12.85 \%$ between 1815 and 1851 (Courville, 1990, p.244), however, once the population of the villages is added, the proportions jumps to $17.01 \%$ and $23.63 \%$ (Courville, 1990, p. 94). This suggests a wide range of non-farm activities available to workers. In addition, farming tied workers to their farms to some extent, but reliance on markets for other products to complement income was crucial. In their comments concerning the economy of Upper Canada at mid-century, Davis and Engerman (1999, p. 14) pointed out that in "the absence of a second source of farm income, workers 
would not have chosen to migrate [to farming] even if, in the long run, farm income would have been more than three times the nonfarm alternative." However, when a second source of income became available, farming became a viable alternative when the "nonfarm income was as high as one half of long-run farm income" Davis and Engerman (1999, p. 14). Complementary income through pluri-activity was thus a crucial determinant of living standards and it would be improper to assume that farming income represented a constant share of total income in all areas of the colony. Dependence on non-farm income hinged on local endowments, access to markets and institutional features which also varied significantly. It follows that there must have been risks in relying solely on agricultural income as the literature has.

Taken together, these reasons suggest that how seigneurial tenure could have acted to slow down growth in Quebec has been misunderstood. We believe that the system should not be seen as creating monopolies, nor as affecting the farm sector primarily. Rather, it should be seen as the creation of monopsonies affecting the non-farm sectors. Under seigneurial tenure, landlords could tax the land area owned by farmers on their estates. In fact, they could tax anyone settling on their estate regardless of the activity performed. Farmers who settled were not free to simply leave their land to settle elsewhere. They had to sell their farms in order to relocate. This seems not to have been an issue in the early days of the colony when land was highly abundant relative to labor. Enforcement was minimal and there was a vibrant renting market before 1760 (Altman, 1983, 1987; Armstrong, 1984a). However, this became progressively more of an issue as population grew altering the land-labor ratio in the favor of landlords. Coupled to this de jure restriction the importance of which grew over time, there was a de facto restriction in the form of the lods et ventes - the tax which represented one twelfth of the proceeds of a land sale. Simultaneously, landlords had the monopoly on the construction of mills and industries in their estates. They earned substantial revenues through these monopolies. To be sure, they could grant permission to entrepreneurs to open industries on their estates, but in that case, not only would they tax these industries under the different land taxes, they would also be allowed to tax them through the lods et ventes if the enterprise were sold. However, it would be theoretically incorrect to consider seigneurial tenures monopoly rights as monopolies. Although it is true that they did have monopolies over certain activities, each seigneur was in competition with the other seigneurs to some small degree - especially for goods intended for world markets in which they were price takers, one example being the flour they produced in their flour mills (Geloso and Lacombe, 2016). In reality, these rights are best considered as monopsonies on local labor markets. On their estates, seigneurs would be the sole demanders of labor (in saw mills, potash plants, carding mills, fulling mills) and of commodities (grains brought to the grist mill). This is because they were not subjecting themselves to their own taxes. If they sold factories to other firms, they did not have to pay the lods et ventes and they did not have to collect the land taxes on the lands occupied by their factories. Thus, they had a strong advantage over non-seigneurial firms in the non-farm sector. This gave them control over the amount of labor demand in some regions. More precisely, seigneurs had strong market power over demand for labor in the non-farm sector in their estates. They would thus determine wage levels by determining the quantity of labor they wanted to employ. Tied to their farms, workers seeking to complement their income in the non-farm industries could hardly move far away. If they wanted to relocate to more auspicious areas, the costs were considerable either through punishment for abandonment or taxation of sale proceeds through the lods et ventes. These monopoly rights of the seigneur, the disadvantageous situation of nonseigneurial firms and the restrictions on mobility fit a standard labor market monopsony 
model (Blair and Harrison, 2010). In addition, the population of Quebec grew at a very brisk pace and claims that seigneurial estates were overcrowded are often made (Ouellet, 1980). This implies that, on top of the restrictions on mobility, a rapidly increasing supply of labor would also have redounded to the seigneur's advantage.

As a monopsony system, seigneurial tenure could have reduced economic growth in Quebec. Recent arguments in the development literature follow this line of reasoning. For example, Barr and Roy (2008) showed that labor market monopsonies lead to suboptimal wages and human capital investments, which consequently lower the rate of economic growth. Barr and Roy (2008) state that monopsony power, based on traveling costs to the workplace, of the firms on the labour market leads to slower economic growth. This is shown through the negative relationship between the monopsony power and wages. Under monopsony, suboptimal wages lead to fewer investments into human capital. Thus, under monopsony, the growth rates of the output would be suboptimal. The given model has two interesting implications for the case of seigneurial tenure in Canada (see Barr and Roy, 2008, p. 1454):

$$
\mu=\frac{\bar{L}\left(2 d-\beta d^{2}\right)}{2 d \bar{L}}=1-\beta \frac{d}{2}=\frac{1}{2}\left(1+\sqrt{1-\frac{\beta F}{\bar{L}}}\right)<1
$$

Where $\mu$ is the fraction of labour employed in production; $\beta$ is units of labour spent on traveling to the firm; $\bar{L} \mathrm{~L}$ is the population of workers in the proximity of the firm ; $d$ is distance to the firm; and $F$ is the minimum amount of labor at which production is possible. Barr and Roy (2008) point out that the fraction of labour employed in production is inversely related to traveling costs. Transposing this relationship into the Canadian economic reality of the early nineteenth century, one can see how this applies. Non-farm labor was not supplied solely by households who devoted their labor exclusively to the nonfarm sector. In fact, as Altman $(1983,1987)$ and Davis and Engerman (1999) suggest, the labor of non-farm sectors would have come largely from households who complemented their farm income in the non-farm sector. Second important implication, is embodied in the equilibrium wage equation (see Barr and Roy, 2008, p. 1454), where $w^{*}$ denotes equilibrium wage:

$$
w^{*}=1-\frac{\beta F}{\bar{L}}<1
$$

Barr and Roy (see 2008, p. 1454) note that the equilibrium wage is decreasing in $\beta$, that is, in travelling costs. Therefore, the monopsony power is inversely related to the wage. This is the second aspect, which we were able to investigate for the Canadian data: whether the tenure had a negative impact on wages.

There is a way to operationalize this insight. In 1791, the British government - after the waves of American loyalists who were hostile to French seigneurial tenure arrived in Canada - voted in a new constitutional act. This act froze the boundaries of seigneurial tenure: all new settlements would have to operate under British freehold tenure while all lands settled pre-1791 would remain under seigneurial tenure. By 1854, the two institutional regimes had co-existed for decades. This provides a natural experiment that we exploit.

\section{New Data and Research Design}

This natural experiment is based on the data from the 1831 and 1851 censuses of Canada. Both censuses describe a high level of institutional mixing in many regions. It is necessary 
to point out that while there were clusters of townships (the Estrie region and the Saguenay region), there were also many townships existing alongside seigneurial estates in the same counties. By the time of the census of 1851-1852, the counties of Vaudreuil (west of Montreal), Two Mountains (north of Montreal), Terrebonne (northeast of Montreal), Rimouski (east of Quebec City), Ottawa, (west of Montreal), Nicolet (south of TroisRivières), Missisquoi (south of Montreal), Islet (south of Quebec City), Montmorency (east of Quebec City), Leinster (North of Montreal), Kamouraska (east of Quebec City), Gaspé (east of Quebec City, close to New Brunswick), Dorchester (south of Quebec City), Bonaventure (east of Quebec City, close to New Brunswick) and Beauharnois (south of Montreal) were all institutionally mixed. In addition, the townships in the Saguenay were predominantly French-speaking and co-exist alongside French-speaking seigneurial estates. In 1851, in the Eastern Townships (Estrie region), there was cultural mixing (roughly 30\% of the population of the area is French-speakingup from 15\% relative to the 1844 census).

In each of the censuses, we wanted to collect the data necessary to measure economic activity in the non-farm sector. Both census ask questions about the number of different plants, factories and mills in each sub-area. Our contention is that we can use the number of each type of plant or factory per inhabitant to proxy the demand for non-farm labor. Then, we can assess whether or not the demand for non-farm labor was greater in nonseigneurial areas while controlling for other factors. For the purposes of identifying the importance of monopsony power, we prefer the census of 1831 to the census of 1851 . This is because, while the census of 1851 provides more reliable estimates of agricultural production, it does not ask any questions about wages and prices. On the other hand, the census of 1831 asks questions about monthly wages, daily wages and wheat prices in each sub-area. This allows us to provide a further step in our methodology: to assess the importance of "monopsony power" in depressing wages in seigneurial areas.

For 1831, small segments of the census rolls are missing and some, even on the microfilm, are unreadable. For example, the entire roll for the Montreal parish and the city of Montreal are missing. ${ }^{2}$ In order to be of use, that census must be combined with the recapitulations contained in the Appendix O.o to the 1832 Journal of the House of Assembly of Lower Canada. There, the aggregated sub-districts data can be found. By mixing the original rolls (some of which are missing) and the parish-level aggregates found in the Appendix to the Journal, we could extract data for the vast majority of the districts in the colony. The completion of that portrait depended on the rolls containing the manuscripts of the census, which can be consulted online at www.familysearch.org (retrieved May 1, 2015). The manuscript rolls are problematic, and using them alone would have made us lose important counties (the entire counties of Montreal, Chambly, Stanstead and Ottawa were not available in the original rolls). However, the manuscripts were useful in numerous instances for obtaining additional pieces of information and completing a few missing observations (the main one being that the county of Rimouski in eastern Quebec had not been compiled in the 1831 census recapitulations in the Appendix, but the rolls are available in full at familysearch.org). In the end, we were able to use the data for all districts in the colony. However, we excluded the counties of Bonaventure and Gaspé (both part of the wider district of Gaspé). Located in the easternmost part of Quebec,

\footnotetext{
${ }^{2}$ A partially nominative census (the head of household supplied his name only, not the names of the other individuals in the household), it contains data on household size, population age structure, religious denominations, herd sizes, surface of land cultivated, harvests of each crop (wheat, peas, oats, barley, rye, corn, potatoes and buckwheat), surface of land occupied, schooling population, number of sawmills, carding mills, flour mills, taverns, distilleries, pearl ash and potash plants, foundries and other industries. It also contains data on wages offered to some laborers by farmers, prices paid in the last year for wheat and the number of individuals who immigrated to the colony since 1825.
} 
the economies of these counties were heavily directed towards fisheries, something that the census was not too concerned about. We thought it wise to exclude them, lest they bias the results. This is not a problem in that their peripheral position to the rest of the colony meant that their populations represented only $2.6 \%$ of the total population of the colony despite initial settlement in the early eighteenth century. For 1851, the observations are available in volumes presented to the government of the Canadas (1853) and recorded at sub-district level. As a result, our dataset from the 1851 census is a cross-sectional dataset of more than 460 districts in the colony. Some areas were excluded, such as the district of Grosse-Île, since it was a quarantine area for immigrants. The data in the 1851 census are much richer, especially in terms of agriculture.

The main disadvantage is that the two censuses do not ask the same questions in terms of industrial activities. Indeed, the 1831 census offers a much wider breakdown of industrial activities than the tables of the 1851 census. That is, there are more numerous types of industries surveyed in 1831 than in 1851. On the other hand, the 1851 census asked questions about the output of firms but reporting was not complete. In addition, the census of 1851 does not ask any questions about wages and prices - something that the 1831 census does as indicated above. The wages that are reported in the 1831 census concern rates for laborers on either daily or monthly basis. Thus, we can use those as proxies for unskilled workers who could derive complementary income in the non-farm sector. In addition, we can deflate wages by the reported prices for wheat in order to obtain grain-wages. In doing so, we can adjust for differing regional purchasing power parities - an important advantage given the wide differences in price levels in the colony (see notably Ouellet et al., 1982) (see notably Ouellet et al. 1982). This is the dataset used by Geloso et al. (2016) in their attempt to measure wages across more than 200 subcounties (accounting for $75 \%$ of the population) in the colony in 1831 . We also use their control variables regarding land quality, distance from urban markets, communication costs, time lapsed since first the first settlement and the number of immigrants per 1,000 inhabitants which are detailed in appendix 1 and have been used also by Geloso et al. (2016) and the control variables for 1851 derived by Arsenault Morin et al. (2015).

Our first step is to assess whether or not the demand for non-farm labor was greater in non-seigneurial areas. We proxy this variable by using the number of plants, mills and factories per 1,000 inhabitants. The first goal in our empirical strategy is to check whether there existed any link between the monopsony tenure regime and the industrial structure. It is not solely the degree of horizontal integration we hope to capture, but rather the development of industries with a relatively higher demand for human capital compared to agriculture. We should note that, by using this proxy, we are biasing our design against our position. We are assuming that one plant per 1,000 inhabitants in a non-seigneurial estate is the same as one plant per 1,000 in a seigneurial estate - that is, that there are no quality differences. This was not the case. For example, flour mills were known to be of superior quality in non-seigneurial areaswhere the legal monopoly did not exist. Settlers in townships refused to build windmills and opted, in spite of their limited capital endowment, to invest in capital-intensive watermills (Deschênes, 2009, p. 148). Historians generally agree that watermills were better for the purposes of milling grain than windmills were - at a lower marginal cost ${ }^{3}$. Thus, the quality of installations in non-seigneurial areas was generally superior.

\footnotetext{
${ }^{3}$ The difference in efficiency in favor of watermills is explained by the fact that millers can control water debit to maximize rotations of the millstones while it is impossible to control wind factors. In fact, operators of windmills had to be especially careful in monitoring the winds, because if they were too strong they could rip the cloth of the blades of the mills.
} 
The non-agricultural sector is complex and therefore we distinguish between heavy and light industries, services or related and other. Since the specific categories slightly changed between censuses we have used the following specifications for 1831 and 1851:

Table 2: Industrial categories

\begin{tabular}{ccc}
\hline Category & $\mathbf{1 8 3 1}$ & $\mathbf{1 8 5 1}$ \\
\hline Heavy & iron plants and foundries & foundries \\
Light broad & grist, saw, fulling and & grist, saw, fulling and \\
& carding mills, potash and distilleries & carding mills, woolen factories \\
& & and distilleries \\
Light core & grist and saw mills, potash & grist and saw mills \\
Other & oil mills, others & breweries and tanneries \\
Services & inns, taverns and shops & stores and shops \\
\hline
\end{tabular}

In Table 3 we report the results for the industrial activities per 1000 population for 1831. The usage of robust standard errors is preferable due to the results of the Breusch and Pagan (1979) and Cook and Weisberg (1983) tests; in cases, where the null of constant variance of the residuals was not rejected at the $5 \%$ level (see Table 9 in the appendix), non-robust standard errors were applied. For heavy industry the significant determinants are land quality and tenure. Whereas land quality has a negative effect, the tenure has a positive one. However, when we exclude low-population areas (those with less than 500 people) as can be seen in Table 4, the effect of tenure for heavy industries disappears. Since the few iron foundries and factories were located in long-settled areas along the St-Lawrence river, Table 3 was probably only capturing the effect that these would not be established in low population areas. For the broad definition of the light industries, the number of immigrants per 1,000 have a negative effect; as well as land quality and tenure. Similar effects are observed for core light industries, with an exception for the land quality. In the latter case tenure regime is also negative and significant. It appears that tenure has a significant positive effect on services. These results hold when we limit the sample to areas with more than 500 inhabitants in Table 4 but the length of the growing season becomes significant. In Table 5 and 6 , we present the results for 1851 using the same design. In this case we do not have a proxy for emigrants or postal zone as a proxy of communication costs, however other controls are the same. The effects are not directly comparable to the ones found in the 1831 data due to differences in categorization. However, one can conclude that tenure regime has a significantly negative impact on broad and core definition of the light industries. The regression models for 1831 industrial structure have a better explanatory power than the ones for 1851. Nevertheless, one finding pierces both samples: the negative relation between the tenure regime and the number of activities in light industry - which comprise the vast majority of all industries.

The next step in our strategy is to analyze the impact of tenure on wages. As indicated above, there are no wage rates associated with the different sub-areas of the colony in 1851, but there is a wide array of wages, monthly and daily, that adjust for differences in regional prices in the census of 1831 (Geloso et al., 2016). The use of wages is crucial to further substantiate our claim of monopsony power. Tables 3 through 6 demonstrate how nonfarming activities were less numerous relative to population in seigneurial areas, but this only captures the non-farm demand for labor and says nothing about the welfare effect. To assess the cogency of the monopsony argument, one would have to find that the greater the monopsony power, the lower the wages. In order to make that determination, we rely on the use of border effects to create a "monopsony power" variable. Our contention is that 
seigneurial areas that were surrounded by other seigneurial domains had a greater level of monopsony power. For residents, given that the legal system was the same everywhere around them, there were no options to which to defect. Thus, seigneurs could easily set the level of employment (leading to a lower-than-equilibrium wage rate) that maximized their profits. However, in a seigneurie neighbouring a non-seigneurial area, that monopsony power was much weaker. Although residents could not easily move, they could provide some work to non-farm industries in non-seigneurial areas. In those areas, seigneurs would have had less monopsony power and thus their ability to control wages and employment in the non-farm would have been much more limited. By using the proximity to different institutional systems, we can thus measure the power of the monopsonist. The greater the power, the lower the wages should have been. Table 7 documents our "monopsony power" variable which will be combined with the same control variables used in Tables 3 and 4 and detailed in Appendix. As one can see, a substantial portion of the sample $(20.55 \%)$ is composed of seigneurial areas with non-seigneurial neighbors. In those areas, seigneurs are expected to have had less power as well. Moreover, non-seigneurial areas with seigneurial neighbors might have had some level of monopsony power. In those places, the labor market may have been tighter because firm owners in these areas might have tried to mimic the behaviour of their seigneurial neighbors.

Table 3: Industrial structure determinants, 1831 all sub-areas

\begin{tabular}{cccccc}
\hline & $(1)$ & $(2)$ & $(3)$ & $(4)$ & $(5)$ \\
Variables & Light core & Light broad & Heavy & Services & Others \\
\hline Tenure & $-5.319^{* * *}$ & $-5.919^{* * *}$ & $0.290^{*}$ & 1.036 & -0.0298 \\
& $(1.452)$ & $(1.473)$ & $(0.147)$ & $(0.705)$ & $(0.125)$ \\
Immigrants per 1,000 & $-0.00802^{* *}$ & $-0.00913^{* *}$ & -0.000213 & $0.00356^{*}$ & 0.000603 \\
& $(0.00400)$ & $(0.00407)$ & $(0.000217)$ & $(0.00200)$ & $(0.000570)$ \\
Share of children & -1.043 & -1.630 & -0.704 & $-8.577^{* *}$ & 0.148 \\
below 14 & $(3.100)$ & $(3.262)$ & $(0.664)$ & $(3.712)$ & $(0.370)$ \\
Avg. farm size & 0.0160 & 0.0302 & 0.00134 & -0.0312 & 0.00340 \\
& $(0.0251)$ & $(0.0265)$ & $(0.00378)$ & $(0.0208)$ & $(0.00238)$ \\
Growing season & -0.0477 & -0.0473 & 0.000110 & $0.0629^{* * *}$ & 0.00145 \\
Years since settlement & $(0.0373)$ & $(0.0386)$ & $(0.00494)$ & $(0.0192)$ & $(0.00338)$ \\
& -0.00448 & -0.00278 & -0.000154 & $0.00840^{*}$ & $-4.80 \mathrm{e}-05$ \\
Postal zone & $(0.00526)$ & $(0.00552)$ & $(0.00112)$ & $(0.00500)$ & $(0.000395)$ \\
& -0.829 & -0.704 & 0.0450 & -0.840 & 0.213 \\
Distance & $(1.106)$ & $(1.115)$ & $(0.146)$ & $(0.857)$ & $(0.194)$ \\
& 0.0227 & 0.0210 & 0.000767 & 0.0319 & -0.00164 \\
Land quality & $(0.0144)$ & $(0.0148)$ & $(0.00155)$ & $(0.0214)$ & $(0.00167)$ \\
& -1.628 & $-2.009 *$ & $-0.227^{*}$ & -0.659 & 0.0238 \\
Constant & $(1.169)$ & $(1.197)$ & $(0.136)$ & $(0.560)$ & $(0.105)$ \\
& $19.24^{* *}$ & $19.89^{* *}$ & 0.165 & $-7.704^{* *}$ & -0.540 \\
R-squared & $(8.297)$ & $(8.591)$ & $(1.088)$ & $(3.487)$ & $(0.820)$ \\
\hline Adjusted R-squared & 0.170 & 0.198 & & & 219 \\
\hline & & & & 0.049 & 0.00242 \\
\hline
\end{tabular}

Robust standard errors in parentheses *** $\mathrm{p}<0.01,{ }^{*} * \mathrm{p}<0.05,{ }^{*} \mathrm{p}<0.1$

The results for wage regressions are reported for all monopsony levels (Table 8 in daily and monthly grain wages). The wages are expressed in bushels of wheat per month or per day. Nominal wages differed across the colony but so did nominal prices for wheat. Thus, 
Table 4: Industrial structure determinants, 1831, sub-areas with population above 500

\begin{tabular}{|c|c|c|c|c|c|}
\hline Variables & $\begin{array}{c}(6) \\
\text { Light core }\end{array}$ & $\begin{array}{c}(7) \\
\text { Light broad }\end{array}$ & $\begin{array}{c}(8) \\
\text { Heavy }\end{array}$ & $\begin{array}{c}(9) \\
\text { Services }\end{array}$ & $\begin{array}{l}(10) \\
\text { Others }\end{array}$ \\
\hline Tenure & $\begin{array}{c}-5.533^{* * *} \\
(1.453)\end{array}$ & $\begin{array}{c}-6.738^{* * *} \\
(1.503)\end{array}$ & $\begin{array}{c}0.234 \\
(0.166)\end{array}$ & $\begin{array}{c}0.458 \\
(0.553)\end{array}$ & $\begin{array}{l}-0.277 \\
(0.199)\end{array}$ \\
\hline Immigrants per 1,000 & $\begin{array}{c}-0.0103^{* * *} \\
(0.00230)\end{array}$ & $\begin{array}{c}-0.0125^{* * *} \\
(0.00243)\end{array}$ & $\begin{array}{l}-0.000369 \\
(0.000268)\end{array}$ & $\begin{array}{l}0.000269 \\
(0.00152)\end{array}$ & $\begin{array}{l}-0.000130 \\
(0.000331)\end{array}$ \\
\hline $\begin{array}{l}\text { Share of population } \\
\text { below } 15\end{array}$ & $\begin{array}{l}-3.201 \\
(2.105)\end{array}$ & $\begin{array}{l}-3.311 \\
(2.302)\end{array}$ & $\begin{array}{l}-0.817 \\
(0.800)\end{array}$ & $\begin{array}{c}-5.027^{* * *} \\
(1.566)\end{array}$ & $\begin{array}{c}0.220 \\
(0.511)\end{array}$ \\
\hline Avg. farm size & $\begin{array}{l}0.00209 \\
(0.0153)\end{array}$ & $\begin{array}{c}0.0161 \\
(0.0181)\end{array}$ & $\begin{array}{l}-0.00153 \\
(0.00391)\end{array}$ & $\begin{array}{l}-0.0117 \\
(0.0124)\end{array}$ & $\begin{array}{c}0.00203 \\
(0.00300)\end{array}$ \\
\hline Growing season & $\begin{array}{c}-0.0719^{* * *} * \\
(0.0221)\end{array}$ & $\begin{array}{c}-0.0744 * * * \\
(0.0256)\end{array}$ & $\begin{array}{c}0.00122 \\
(0.00507)\end{array}$ & $\begin{array}{c}0.0532^{* * * *} \\
(0.0161)\end{array}$ & $\begin{array}{c}0.00374 \\
(0.00275)\end{array}$ \\
\hline Years since settlement & $\begin{array}{l}-0.00280 \\
(0.00448)\end{array}$ & $\begin{array}{l}-0.00152 \\
(0.00473)\end{array}$ & $\begin{array}{l}0.000179 \\
(0.00123)\end{array}$ & $\begin{array}{c}0.00532 \\
(0.00372)\end{array}$ & $\begin{array}{c}4.19 \mathrm{e}-05 \\
(0.000342)\end{array}$ \\
\hline Postal zone & $\begin{array}{l}-0.995 \\
(1.070)\end{array}$ & $\begin{array}{l}-0.616 \\
(1.084)\end{array}$ & $\begin{array}{l}-0.101 \\
(0.185)\end{array}$ & $\begin{array}{c}0.360 \\
(0.449)\end{array}$ & $\begin{array}{c}0.341 \\
(0.288)\end{array}$ \\
\hline Distance & $\begin{array}{c}0.0116 \\
(0.0134)\end{array}$ & $\begin{array}{l}0.00664 \\
(0.0139)\end{array}$ & $\begin{array}{c}0.00418 \\
(0.00272)\end{array}$ & $\begin{array}{c}0.00431 \\
(0.00706)\end{array}$ & $\begin{array}{l}-0.00308 \\
(0.00324)\end{array}$ \\
\hline Land quality & $\begin{array}{l}-1.155 \\
(0.708)\end{array}$ & $\begin{array}{l}-1.525^{*} \\
(0.800)\end{array}$ & $\begin{array}{l}-0.267^{*} \\
(0.146)\end{array}$ & $\begin{array}{l}-0.866^{*} \\
(0.522)\end{array}$ & $\begin{array}{l}-0.0742 \\
(0.0864)\end{array}$ \\
\hline Constant & $\begin{array}{c}25.72^{* * *} \\
(5.723)\end{array}$ & $\begin{array}{c}27.31^{* * * *} \\
(6.462)\end{array}$ & $\begin{array}{c}0.146 \\
(1.140)\end{array}$ & $\begin{array}{c}-6.904^{* *} \\
(3.417)\end{array}$ & $\begin{array}{l}-0.798 \\
(0.722)\end{array}$ \\
\hline Observations & 188 & 188 & 188 & 188 & 188 \\
\hline R-squared & 0.322 & 0.379 & 0.041 & 0.106 & 0.101 \\
\hline Adjusted R-squared & 0.288 & 0.347 & 0 & 0.0612 & 0.0559 \\
\hline
\end{tabular}

Robust standard errors in parentheses

${ }^{* * *} \mathrm{p}<0.01,{ }^{* *} \mathrm{p}<0.05,{ }^{*} \mathrm{p}<0.1$ 
Table 5: Industrial structure determinants, 1851 all sub-areas

\begin{tabular}{cccccc}
\hline & $(11)$ & $(12)$ & $(13)$ & $(14)$ & $(15)$ \\
Variables & Light core & Light broad & Heavy & Services & Others \\
\hline Tenure & & & & & \\
& $-2.738^{* * *}$ & $-2.751^{* * *}$ & 0.00651 & $2.675^{* * *}$ & 0.0564 \\
Share of population & $(0.581)$ & $(0.595)$ & $(0.0214)$ & $(0.991)$ & $(0.106)$ \\
below 15 & $-2.141^{* *}$ & $-2.483^{* *}$ & 0.0283 & 2.865 & 2.490 \\
Avg. farm size & $(1.028)$ & $(1.033)$ & $(0.0708)$ & $(4.910)$ & $(2.257)$ \\
& 0.00492 & 0.00524 & -0.000263 & -0.0160 & -0.000840 \\
Growing season & $(0.00347)$ & $(0.00384)$ & $(0.000165)$ & $(0.0126)$ & $(0.000987)$ \\
& $-0.0571^{* *}$ & $-0.0636^{* * *}$ & $0.00196^{*}$ & $0.0871^{* *}$ & 0.00860 \\
Distance & $(0.0225)$ & $(0.0234)$ & $(0.00102)$ & $(0.0393)$ & $(0.00548)$ \\
& -0.000726 & -0.00176 & $3.53 \mathrm{e}-05$ & 0.00715 & $-9.34 \mathrm{e}-05$ \\
Land quality & $(0.00275)$ & $(0.00280)$ & $(6.42 \mathrm{e}-05)$ & $(0.00548)$ & $(0.000385)$ \\
& $-1.059^{*}$ & -0.929 & -0.0151 & 1.499 & 0.145 \\
Constant & $(0.614)$ & $(0.660)$ & $(0.0308)$ & $(1.364)$ & $(0.209)$ \\
& $17.16^{* * *}$ & $18.89^{* * *}$ & $-0.362^{*}$ & $-15.38^{* *}$ & $-2.652^{*}$ \\
& $(4.720)$ & $(4.872)$ & $(0.197)$ & $(7.715)$ & $(1.559)$ \\
Observations & 455 & 455 & 443 & 455 & 455 \\
R-squared & 0.137 & 0.126 & 0.017 & 0.056 & 0.122 \\
Adjusted R-squared & 0.125 & 0.114 & 0.00389 & 0.0429 & 0.110 \\
\hline
\end{tabular}

Robust standard errors in parentheses

*** $\mathrm{p}<0.01,{ }^{*} * \mathrm{p}<0.05,{ }^{*} \mathrm{p}<0.1$

Table 6: Industrial structure determinants, 1851 sub-areas with population above 500

\begin{tabular}{cccccc}
\hline & $(16)$ & $(17)$ & $(18)$ & $(19)$ & $(20)$ \\
Variables & Light core & Light broad & Heavy & Services & Others \\
\hline & & & & & \\
Tenure & $-2.027^{* * *}$ & $-2.090^{* * *}$ & -0.00661 & $2.243^{* *}$ & -0.128 \\
& $(0.470)$ & $(0.494)$ & $(0.0295)$ & $(1.085)$ & $(0.149)$ \\
Share of population & -0.808 & $-1.482^{*}$ & 0.107 & 4.467 & $6.885^{*}$ \\
below 15 & $(0.790)$ & $(0.881)$ & $(0.284)$ & $(7.522)$ & $(3.886)$ \\
Avg. farm size & 0.00276 & 0.00263 & -0.000334 & -0.00477 & -0.000390 \\
& $(0.00346)$ & $(0.00399)$ & $(0.000229)$ & $(0.0166)$ & $(0.00158)$ \\
Growing season & $-0.0496^{* * *}$ & $-0.0581^{* * *}$ & 0.00202 & 0.0587 & 0.00358 \\
& $(0.0148)$ & $(0.0163)$ & $(0.00128)$ & $(0.0402)$ & $(0.00743)$ \\
Distance & -0.00244 & -0.00366 & $1.89 \mathrm{e}-05$ & 0.00693 & -0.000511 \\
& $(0.00270)$ & $(0.00276)$ & $(8.51 \mathrm{e}-05)$ & $(0.00632)$ & $(0.000577)$ \\
Land quality & $-0.795^{*}$ & -0.690 & -0.0207 & 1.827 & 0.204 \\
& $(0.435)$ & $(0.488)$ & $(0.0366)$ & $(1.335)$ & $(0.233)$ \\
Constant & $14.43^{* * *}$ & $16.82^{* * *}$ & -0.389 & -10.66 & $-3.466^{*}$ \\
& $(3.093)$ & $(3.388)$ & $(0.241)$ & $(8.198)$ & $(1.843)$ \\
& & & & & \\
\hline Observations & 379 & 379 & 367 & 379 & 379 \\
R-squared & 0.178 & 0.160 & 0.019 & 0.043 & 0.312 \\
Adjusted R-squared & 0.165 & 0.146 & 0.00311 & 0.0271 & 0.301 \\
\hline
\end{tabular}

Robust standard errors in parentheses

*** $\mathrm{p}<0.01,{ }^{*} * \mathrm{p}<0.05,{ }^{*} \mathrm{p}<0.1$ 
Table 7: A proxy for monopsony power

\begin{tabular}{cccc}
\hline Monopsony power & Status & Frequency & $\%$ \\
\hline 0 & Non-seigneurial areas surrounded by other & 35 & 15.98 \\
& non-seigneurial areas & & \\
1 & Non-seigneurial areas with seigneurial neighbors & 15 & 6.85 \\
2 & Seigneurial areas with non-seigneurial neighbors & 45 & 20.55 \\
3 & Seigneurial areas with seigneurial neighbors & 124 & 56.62 \\
\hline
\end{tabular}

the use of a ratio of wages to grain prices provides us with a real wage measure that controls for price differences. In reading Table 8, one should see the effect in terms of the wage rate expressed in bushels of wheat per month or day. The monthly grain wages are useful, but not the most reliable, as they pertained only to monthly wages in agriculture and included payments-in-kind which were not recorded but must have varied greatly across regions. The daily wages are relevant for labourers without a specific focus on agriculture, thus a better measure for unskilled workers. However, this makes no difference. For both daily and monthly grain wages, the greater the level of monopsony power, the lower wages were relative to areas with no monopsony power (non-seigneurial areas surrounded by non-seigneurial areas). Even when we focus on areas with more than 500 inhabitants, the results stay the same. The areas with highest level of monopsony power offered monthly grain 3.34 to 3.76 bushels per month less than those with no monopsony power, while the proportion for daily wages stood at 0.13 to 0.15 fewer bushels per day. To put things into proportion, the monthly grain wages stood at 7.14 bushels per month in non-seigneurial areas compared with 4.36 in seigneurial areas. For daily wages, these proportions stand at 0.38 and 0.32 bushels per day, respectively.

These are significant differences obtained in spite of a number of environmental factors that played against non-seigneurial areas. Geloso et al. (2016); Altman (1998) pointed out that seigneurial areas tended to be on better lands, closer to urban centres with access to a better road network and settled by individuals who were accustomed to the rigours of Canada. In Table 8, the variable for the ratio of immigrants who had arrived from Great Britain in the past five years to the local population is always negative. Immigrants, who generally settled in freehold areas, assumed a penalty relative to natives as they were unfamiliar with Canadas rough environment and this slightly depressed their productivity. Negative coefficients are also found for the land quality and recency of settlement variables. All of these variables tend to play against non-seigneurial areas. As a result, if one simply looks at uncontrolled differences, all of these factors are acting to hide the effects caused by institutions. Had there been a colony-wide absence of seigneurial tenure, the areas that were under freehold tenure in 1831 would have had lower wages relative to seigneurial estate given the poorer environmental endowments they possessed which is the same as saying that seigneurial tenure offset the benefits of the rich endowments in the areas where it was in place. This is why, we argue, the coefficients are so considerable since the regressions control for confounding environmental factors. 
Table 8: Effect of monopsony power on wage rates

\begin{tabular}{ccccc}
\hline & $(21)$ & $(22)$ & $(23)$ & $(24)$ \\
Variables & Monthly grain & Monthly grain & Daily grain & Daily grain \\
\hline Monopsony power, 1 & $-1.484^{* * *}$ & $-1.357^{* * *}$ & -0.0372 & 0.00372 \\
& $(0.431)$ & $(0.500)$ & $(0.0272)$ & $(0.0283)$ \\
Monopsony power, 2 & $-3.100^{* * *}$ & $-3.242^{* * *}$ & $-0.128^{* * *}$ & $-0.149^{* * *}$ \\
& $(0.405)$ & $(0.433)$ & $(0.0251)$ & $(0.0244)$ \\
Monopsony power, 3 & $-3.342^{* * *}$ & $-3.757^{* * *}$ & $-0.131^{* * *}$ & $-0.145^{* * *}$ \\
& $(0.398)$ & $(0.428)$ & $(0.0230)$ & $(0.0241)$ \\
Immigrants per 1,000 & $-0.00273^{* * *}$ & $-0.00265^{* *}$ & $-0.000100^{* *}$ & $-0.000157^{* *}$ \\
& $(0.00102)$ & $(0.00108)$ & $(4.41 \mathrm{e}-05)$ & $(6.16 \mathrm{e}-05)$ \\
Share of children & -0.704 & -0.428 & 0.0624 & $0.109^{*}$ \\
below 14 & $(0.912)$ & $(0.971)$ & $(0.0463)$ & $(0.0554)$ \\
Avg. farm size & -0.00230 & -0.00229 & $-0.00105^{* * *}$ & $-0.00113^{* *}$ \\
& $(0.00727)$ & $(0.00764)$ & $(0.000344)$ & $(0.000436)$ \\
Growing season & $0.0202^{*}$ & 0.00218 & $-2.59 \mathrm{e}-05$ & -0.000237 \\
& $(0.0118)$ & $(0.0120)$ & $(0.000653)$ & $(0.000687)$ \\
Years since settlement & -0.000721 & -0.00344 & $0.000447^{* * *}$ & $0.000414^{* * *}$ \\
Postal zone & $(0.00245)$ & $(0.00246)$ & $(0.000108)$ & $(0.000141)$ \\
& 0.260 & $0.657^{* *}$ & -0.0159 & -0.0133 \\
Distance & $(0.269)$ & $(0.326)$ & $(0.0138)$ & $(0.0186)$ \\
& 0.00134 & $-0.0140^{* *}$ & $0.000266^{*}$ & 0.000265 \\
Land quality & $(0.00355)$ & $(0.00554)$ & $(0.000161)$ & $(0.000316)$ \\
& $0.964^{* * *}$ & $1.284^{* * *}$ & $0.0571^{* * *}$ & $0.0670^{* * *}$ \\
Constant & $(0.362)$ & $(0.364)$ & $(0.0200)$ & $(0.0208)$ \\
& 3.215 & $7.389^{* * *}$ & $0.399^{* * *}$ & $0.439^{* * *}$ \\
Sample & $(2.607)$ & $(2.649)$ & $(0.148)$ & $(0.151)$ \\
R-squared & & & & \\
Adjusted R-squared & all & $>500 \mathrm{dwellers}$ & all & $>500 \mathrm{dwellers}$ \\
& 211 & 181 & 213 & 182 \\
& 0.542 & 0.508 & 0.255 & 0.300 \\
& 0.517 & 0.476 & 0.214 & 0.254 \\
\hline
\end{tabular}

Standard errors in parentheses for columns 21, 22 and 24;

Robust standard errors in parentheses for 23

*** $\mathrm{p}<0.01,{ }^{* *} \mathrm{p}<0.05,{ }^{*} \mathrm{p}<0.1$ 


\section{Conclusion}

This paper contributes to the debate on the role of institutional regimes in economic history. Using the Barr and Roy (2008) model of economic growth under a monopsonic labour market, we demonstrate the implications of Seigneurial tenure for the Quebec economy: theoretically, the monopsonic regime is associated with a lower fraction of labour employed in production and lower wages. Further we approach the issue empirically and investigate whether the Seigneurial tenure regime had a long-lasting impact on industrial structure and wages in the Quebec economy of the nineteenth century. New data on the industrial structure and wages allow us to capture the determinants of industrial activities, a proxy for horizontal integration, and wages, a proxy for income. We conduct two sets of regressions. Firstly, we identify the determinants of industrial activities. Here we find tenure to be a robust negative determinant for light industries in both samples: 1831 and 1851. Secondly, we build a monopsony power variable based on the types of tenure surrounding each area. We find that, the greater the monopsony power, the lower the wage rates expressed in bushels of grain. Our findings emphasize the negative role of seigneurial tenure as a monopsony-like institutional regime in Canadian economic history and invite further research on the given issue. Particular focus should be given to the role of flour mills which were the exclusive right of seigneuries. Since peasants were not allowed to bring their grain to any other mill than that of their seigneur, these were monopsonies over each local grain market which may have incited peasants to shift towards different types of crops that would not have been optimal. Another channel would be to use the school attendance statistics censuses preceding and following the abolition of seigneurial tenure using a difference-in-difference approach. If there was a change in behavior towards human capital investment, this would be further confirmation of the monopsony effect of seigneurial tenure. In any case, we believe that we have elaborated a strong theoretical and empirical case for considering seigneurial tenure as a monopsony to explain how it could have mattered in Canadian economic history.

\section{Appendix}

\section{Length of Growing Season}

The length of the growing season is derived from the Centre de Référence en Agriculture et Agroalimentaire du Québec (2012), produced in collaboration with the agriculture department of the province. It is freely available online at www.agrometeo.org, and under the heading "saison de croissance" we can find maps of the average length of the growing season based on the average length observed from 1979 to 2008.

\section{Land Quality}

The maps pertaining to the soil capability for agriculture were obtained from the Canada Center for Remote Sensing Natural Resources Canada, in a digital format. The Agriculture and Agri-Food Canada (1998) (Canada Land Inventory, or CLI) 1:250 000 data were further processed in the ArcGIS software and projected in the NAD 1983 Quebec Lambert conform conical projection after conversion to the ESRI Shapefile format. Official municipal boundaries from the Ministère des Ressources naturelles du Québec (Quebec's Natural Resources Ministry) were used both to provide a shoreline limit to the CLI dataset and to enable the use of land quality statistics on a per-municipality basis. 
To this end, the Identity Analysis tool was used to splice together data from the CLI, which are distributed in small subunits conforming to the National Topographic System of Canada layout, and we then proceeded to associate agricultural land quality attributes to the municipal features using the Intersect Analysis tool. The data frame attributes were set to update the geometry attributes of area to hectares and perimeter length to kilometres. Attribute tables resulting from the GIS processing were then imported in spreadsheet software and aggregated using Pivot tables based on municipalities, regional county municipalities, and administrative regions.

The CLI contains attributes that describe the proportion, rounded in tenths, of the surface of an agricultural land feature corresponding to a qualitative classification scale, ranging from 1 to 7 . The best agricultural areas, with the least limitations, are assigned low numbers (1), with worsening limitations resulting in higher class values (7). Organic soils (i.e. significant peat bogs), non-classified areas for the purpose of agriculture (i.e. built up areas, national parks, nature preserves) and water are also assigned specific class values. The data attributes provide the three most dominant land quality classes of a feature, their proportion, and the type of limitation encountered. These limitations can be broadly defined as being of a climatic, geological or hydrological nature. With the total area (in hectares) of any feature, and the proportion of these features corresponding to the soil capability classification in terms of quality and limitations, statistics in terms of both relative and absolute area of potential agricultural land for municipalities are thus available simply by multiplying them and summing them up.

Finally, for the regressions, we computed the land quality as the share of all land of quality 1 to 3 relative to the amount of land already cleared in 1831. This gave us an idea of how much quality land was being farmed and what quality land for farming was left.

\section{Distance from Nearest Urban Centre}

This variable is based on associating a direct line estimate of the distance between a given area and the nearest of three largest cities in the colony at the time: Montreal, Trois-Rivières and Quebec City. The distance is reported in kilometers.

\section{Immigrants per 1,000}

The census of 1831 (in Government of the Province of Canada, 1853) contains three headings regarding people who immigrated from the British Isles to Canada since 1825 by sea, by land or foreigners who immigrated since 1825 regardless of the manner of entry. The data from the 1831 census report that only 23,426 persons were alive and had arrived in Lower Canada since 1825. The vast majority of them were located in townships.

\section{Years Since First Settlement}

The aggregated data in the Appendix to the Journal of the House of Assembly provide the settlement data of some parishes or townships in each district. But not all commissioners reported this information. As a result, we had to turn to the Dictionnaire des Paroisses, Missions et Municipalités de la Province de Québec, from Magnan (1925). This document allowed us to confirm the dates provided in the Appendix. However, there are some issues. Sometimes, the documents cite the point of settlement, the canonical erection and the concession of an estate. In some instances, all three dates are the same. Not always. As a result, we opted for the rule of using the earliest date available in all instances. 


\section{Postal Zone}

The postal zones were derived based on the schedule of postal rates mentioned in the 1831 Almanac for Montreal (Unknown, 1831, p. 37). The rate of 4.5 pence applied to all mail carried within less than 60 miles. The rate of 7 pence applied to mail sent between 60 and 100 miles away. The rate of 9 pence applied to mail sent up to 200 miles away. Each represented a zone and we created a variable capturing this postal zone to measure communication costs.

\section{Share of population below 14}

Indirectly, this is meant to capture demographic factors affecting the labor supply. FrenchCanadians were known to have very large families (well above the average of Europe and above the level observed in the United States). As Lindert and Williamson (2016) point out with regards to colonial America, the high dependency rates of the American population meant that there was a constraint on the labor supply of some household members and, when comparing with England and its smaller families, this affected the comparison of living standards. Thus, we controlled for this factor. The share of population is derived based on the categories provided in the censuses.

\section{Average Farm Size}

This variable is meant to capture the importance of farming as a competitor to non-farm labor. The larger the farms, the greater the tendency for hired farm help to be present. The census of 1831 provided a heading asking the number of families earning their mainstay from agriculture. We took the amount of land cleared and divided it by the number of farm households. With the exception of the county of Stanstead, these were well reported and matched the numbers of those whose occupations, reported in a different heading, was agriculturally-related. For Stanstead, we divided by the number of total households.

Table 9: Breusch and Pagan (1979) / Cook and Weisberg (1983) test p-values

\begin{tabular}{cccccccccc}
\hline Column & Table 3 & Column & Table 4 & Column & Table 5 & Column & Table 6 & Column & Table 8 \\
\hline 1 & 0 & 6 & 0 & 11 & 0 & 16 & 0 & 21 & 0.7236 \\
2 & 0 & 7 & 0 & 12 & 0 & 17 & 0 & 22 & 0.987 \\
3 & 0 & 8 & 0 & 13 & 0 & 18 & 0 & 23 & 0.0289 \\
4 & 0 & 9 & 0.0088 & 14 & 0 & 19 & 0 & 24 & 0.051 \\
5 & 0 & 10 & 0 & 15 & 0 & 20 & 0 & & \\
\hline
\end{tabular}

\section{References}

Agriculture and Agri-Food Canada (1998). Canada Land Inventory, National Soil Database. Government of Canada.

Altman, M. (1983). Seignorial Tenure in New France, 1688-1739: An Essay on Income Distribution and Retarded Economic Development. Historical Reflections / Réflexions historiques, 10(3):335-375.

Altman, M. (1987). Note on the Economic Burden of the Seigniorial System in New France, 1688-1739. Historical Reflections / Réflexions historiques, 14(1):135-142. 
Altman, M. (1998). Land Tenure, Ethnicity, and the Condition of Agricultural Income and Productivity in Mid-Nineteenth-Century Quebec. Agricultural History, 72(4):708-762.

Altman, M. (2003). Staple theory and export-led growth: constructing differential growth. Australian Economic History Review, 43(3):230-255.

Armstrong, R. (1984a). Structure and Change: An Economic History of Quebec. Gage Publishing.

Armstrong, R. (1984b). The Efficiency of Quebec Farmers in 1851. Histoire sociale / Social history, 17(33):149-163.

Arsenault Morin, A., Geloso, V., and Kufenko, V. (2015). Infant Mortality and the Role of Seigneurial Tenure in Canada East, 1851. Working paper no.47/2015, University of Hohenheim Department of Economics.

Arsenault Morin, A., Geloso, V., and Kufenko, V. (2016). The Heights of French-Canadian, Irish, Scottish and English Populations in Quebec, 1813 to 1847. Working paper no.233/2016, Department of Economic History at the London School of Economics.

Bardhan, P. (1984). Land, Labor, and Rural Poverty: Essays in Development Economics. Columbia University Press.

Barr, T. and Roy, U. (2008). The effect of labor market monopsony on economic growth. Journal of Macroeconomics, 30(4):1446-1467.

Blair, R. and Harrison, J. (2010). Monopsony in Law and Economics. Cambridge University Press.

Bouchard, G. (1996). Quelques arpents d'Amérique: population, économie, famille au Saguenay, 1838 - 1971. Boréal.

Breusch, T. and Pagan, A. (1979). A simple test for heteroscedasticity and random coefficient variation. Econometrica, 47(5):1287-1294.

Centre de Référence en Agriculture et Agroalimentaire du Québec (2012). Atlas Agroclimatique du Québec.

Cook, D. and Weisberg, S. (1983). Diagnostics for heteroscedasticity in regression. Biometrika, 70(1):1-10.

Courville, S. (1990). Entre Ville et Campagne: l'essor du village dans les seigneuries du Bas-Canada. Presses de l'Université Laval.

Courville, S. (2008). Quebec: A Historical Geography. University of British Columbia Press.

Cranfield, J. and Inwood, K. (2007). The great transformation: A long-run perspective on physical well-being in Canada. Economics and Human Biology, 5(2):204-228.

Davis, L. and Engerman, S. (1999). The Economy of British North America: Miles Traveled, Miles Still to Go. William and Mary Quarterly, 56(1):9-22.

Dennison, T. (2011). The institutional framework of Russian serfdom. Cambridge University Press. 
Deschênes, G. (2009). Quand le vent faisait tourner les moulins: trois siècles de meunerie banale et marchande au Québec. Septentrion.

Dong, X.-Y. and Putterman, L. (2000). Prereform industry and state monopsony in China. Journal of Comparative Economics, 28(1):32-60.

Dong, X.-Y. and Putterman, L. (2002). China's state-owned enterprises in the first reform decade: An analysis of a declining monopsony. Economics of Planning, 35(2):109-139.

Egnal, M. (1996). Divergent Paths: How Culture and Institutions have shaped North American Growth. Oxford University Press.

Fleisher, B. and Wang, X. (2004). Skill differentials, return to schooling, and market segmentation in a transition economy: the case of Mainland China. Journal of Development Economics, 73(1):315-328.

Geloso, V., Kufenko, V., and Villeneuve, R. (2016). Living Standards in Lower Canada, 1831. Submitted manuscript under revision.

Geloso, V. and Lacombe, A. (2016). Why was flour of poor quality? The impact of Seigneurial laws and price controls on flour in Quebec. Agricultural History Review, 64(2):forthcoming.

Government of the Province of Canada (1853). Census of the Canadas, 1851-1852, Volumes I and II. John Lowell Printer.

Green, A. (1969). Regional Inequality, Structural Change, and Economic Growth in Canada. 1890-1956. Economic Development and Cultural Change, 17(4):567-583.

Grenier, B. (2012). Une brève histoire du régime seigneurial. Boréal.

Harris, C. (2012). Le Pays Revêche : Société, espace et environnement au Canada avant la Confédération. Presses de l'Université Laval.

House of Assembly of Lower Canada (1832). Appendix O.o to the XLIst volume to the Journals of the House of Assembly of Lower Canada. Neilson and Cowan.

Inwood, K. and Irwin, J. (1993). Canadian Regional Commodity Income Differences at Confederation. In Inwood, K., editor, Farm, Factory and Fortune, pages 93-120. Acadiensis Press, Fredericton.

Inwood, K. and Irwin, J. (2002). Land, income and regional inequality: New estimates of provincial incomes and growth in Canada, 1871-1891. Acadiensis, 31(2):157-184.

Jones, R. (1942). French-Canadian Agriculture in the St. Lawrence Valley, 1815-1850. Agricultural History, 16(3):137148.

Jones, R. (1946). Agriculture in Lower Canada, 1792-1815. Canadian Historical Review, $37: 33-51$.

Lewis, F. and McInnis, M. (1980). The Efficiency of the French-Canadian Farmer in the Nineteenth Century. Journal of Economic History, 40(3):497-514.

Lewis, F. and McInnis, M. (1984). Agricultural Output and Efficiency in Lower Canada, 1851. Research in Economic History, 9:45-87. 
Lindert, P. and Williamson, J. (2016). Unequal Gains: American Growth and Inequality since 1700. Princeton University Press.

Magnan, H. (1925). Dictionnaire historique et géographique des paroisses, missions et municipalités de la province de Québec. Imprimeries Arthabaska.

Martin, R. M. (1838). History, Statistics and Geography of Upper and Lower Canada. Whittaker and Co.

McInnis, M. (1992). Perspectives on Ontario agriculture. Langdale Press.

Ogilvie, S. (2001). The economic world of the Bohemian Serf: economic concepts, preferences, and constraints on the estate of Friedland, 1583-1692. Economic History Review, 54(3):430-453.

Ogilvie, S. and Carus, A. (2014). Institutions and economic growth in historical perspectives. In Aghion, P. and Durlauf, S., editors, Handbook of Economic Growth, Vol 2A, pages 403-513. North Holland.

Ouellet, F. (1966). Histoire économique et sociale du Québec, 1760 - 1850. Éditions Fides.

Ouellet, F. (1980). Lower Canada, 1791-1840: Social Change and Nationalism. McClelland and Stewart Limited.

Ouellet, F., Hamelin, J., and Chabot, R. (1982). Les prix agricoles dans les villes et les campagnes du Québec d'avant 1850: apercus quantitatifs. Historie Sociale, Vol 15, No 29:83-127.

Percy, M. and Szostak, R. (1992). The Political Economy of the Abolition of Seigneurial Tenure in Canada East. Explorations in Economic History, 29(1):51-68.

Phillips, P. (1974). Land Tenure and Economic Development: a comparison of Upper and Lower Canada. Journal of Canadian Studies, 9(2):35-45.

Public Archives of Canada (1876). Censuses of Canada, 1665 to 1871, Vol.4. Department of Agriculture of Canada.

Quebec Mercury (1831). Quebec mercury, 1805 to 1903.

Russell, P. (2012). How Agriculture Made Canada: Farming in the Nineteenth Century. McGill-Queens University Press.

Unknown (1831). The Montreal Almanack or Lower Canada Register for 1831, being third after leap year. Robert Armour. 


\section{SCHRIFTENREIHE DES \\ PROMOTIONSSCHWERPUNKTS \\ GLOBALISIERUNG UND BESCHÄFTIGUNG}

Nr. 1/1998 Bernhard Holwegler und Hans-Michael Trautwein, Beschäftigungswirkungen der Internationalisierung, eine Studie aus- und einfließender Direktinvestitionen der Metall- und Elektroindustrie im Raum Stuttgart

Nr. 2/1998 Heinz-Peter Spahn, Heterogeneous Labour, the Unemployment Equilibrium, and the Natural Rate

Nr. 3/1998 Philip Arestis, Iris Biefang-Frisancho Mariscal and Harald Hagemann, Capital Shortage Unemployment in Germany and the UK

Nr. 4/1999 Theo Schewe, Full Employment in the Age of Globalisation? PoliticalEconomic Analysis of Effective Employment Policies in the Nineties. The Case of Norway.

Nr. 5/1999 Hagen Krämer, Dienstleistungen: Motor für Wachstum und Beschäftigung in Deutschland?

Nr. 6/1999 Jürgen Kromphardt, Lohnbildung und Beschäftigung

Nr. 7/1999 Ewald Walterskirchen, Beschäftigungspolitik in Österreich

Nr. 8/1999 Reiner Franke, Lohnzurückhaltung, Beschäftigung und (zu) einfache empirische Zusammenhänge

Nr. 9/1999 Peter Kalmbach, Implications of Integration for Wage Formation and Employment

Nr. 10/2000 Arne Heise, Theoretische Grundlagen einer Verhaltensabstimmung der makroökonomischen Politikträger

Nr. 11/2000 Eckhard Hein und Carsten Ochsen, Monetary Interest Rates, Income Shares, and Investment: Theory and Empirical Evidence for France, Germany, the UK, and the USA

Nr. 12/2000 Guntram R. M. Hepperle, Airbus - ein gelungenes Beispiel für beschäftigungsorientierte Industriepolitik?

Nr. 13/2000 Bernhard Holwegler, Implikationen der Technologiediffusion für technologische Arbeitslosigkeit

Nr. 14/2000 Markus Schreyer, Wachstum und Beschäftigung vor dem Hintergrund des Solowschen Produktivitätsparadoxons

Nr. 15/2000 Mauro Boianovsky, Some Cambridge Reactions to The General Theory: David Champernowne and Joan Robinson on Full Employment

Nr. 16/2001 Marc-Peter Radke, Law and Economics of Microsoft vs. U.S. Department of Justice: A New Economic Paradigm for Antitrust in Network Markets or Inefficient Lock-in of Antitrust Policy?

Nr. 17/2001 Daniel Hartmann, Taylor-Regel und amerikanische Geldpolitik 
Nr. $18 / 2002$

Nr. 19/2002

Nr. 20/2004

Nr. $21 / 2004$

Nr. $22 / 2005$

Nr. 23/2006

Nr. $24 / 2007$

Nr. 25/2007

Nr. $26 / 2008$

Nr. 27/2009

Nr. 28/2009

Nr. 29/2009

Nr. 30/2009

Nr. 31/2010

Nr. 32/2010

Nr. 33/2011

Nr. 34/2011

Nr. 35/2011

Nr. 36/2012

Nr. 37/2012

Nr. 38/2012
Jutta Maute, Stabilization via Currency Board

Daniel Hartmann, The Fed Strategy: Successful but Out-of-Date?

Dirk H. Ehnts, Spatial Decisions of Multinational Enterprises and their Effect on Local Firms

Theo Schewe, Makroökonomische Probleme des extensiven Rohstoffexports in einer entwickelten Volkswirtschaft - analysiert am Beispiel der norwegischen Erdölwirtschaft

Georg Erber \& Aida Sayed-Ahmed, Offshore Outsourcing - A global shift in the present IT industry

Deborah Schöller, Service Offshoring: A Challenge for Employment? Evidence from Germany

Ralf Rukwid, Arbeitslosigkeit und Lohnspreizung - Empirische Befunde zur Arbeitsmarktsituation gering Qualifizierter in Deutschland

Julian P. Christ, Varieties of Systems of Innovation: A Survey of their Evolution in Growth Theory and Economic Geography

Andreja Benković \& Juan Felipe Mejía, Tourism as a Driver of Economic Development: The Colombian Experience

Julian P. Christ \& André P. Slowak, Standard-Setting and Knowledge Dynamics in Innovation Clusters

Constanze Dobler, The Impact of Institutions, Culture, and Religion on Per Capita Income

Julian P. Christ \& André P. Slowak, Why Blu-ray vs. HD-DVD is not VHS vs. Betamax: The Co-evolution of Standard-setting Consortia

Patricia Hofmann, Die neue neue Außenhandelstheorie: das Melitz-Modell

Julian P. Christ, The Geography and Co-location of EuropeanTechnologyspecific Co-inventorship Networks

Julian P. Christ, Geographic Concentration and Spatial Inequality: Two Decades of EPO Patenting at the Level of European Micro Regions

Finn Marten Körner, An Equilibrium Model of 'Global Imbalances' Revisited

Constanze Dobler \& Harald Hagemann, Economic Growth in the PostSocialist Russian Federation after 1991: The Role of Institutions

Constanze Dobler, Instability, Economic Stagnation and the Role of Islam in the North Caucasus

Georg Erber und Harald Hagemann, Wachstums- und Investitionsdynamik in Deutschland

Ralf Rukwid, Grenzen der Bildungsexpansion? Ausbildungsinadäquate Beschäftigung von Ausbildungs- und Hochschulabsolventen in Deutschland Vadim Kufenko, Empirical Analysis of Regional Economic Performance in Russia: Human Capital Perspective 
Nr. 39/2013 Harald Hagemann und Vadim Kufenko, The Political Kuznets Curve for Russia: Income Inequality, Rent Seeking Regional Elites and Empirical Determinants of Protests during 2011/2012

Nr. 40/2014 Danila Raskov und Vadim Kufenko, The Role of Old Believers'Enterprises: Evidence from the Nineteenth Century Moscow Textile Industry

Nr. 41/2014 Harald Hagemann, Georg Erber, Niels Geiger, Johannes Schwarzer und Oliver Zwiessler, Wachstums- und Investitionsdynamik in Deutschland

Nr. 42/2015 Vincent Geloso und Vadim Kufenko, Malthusian Pressures: Empirical Evidence from a Frontier Economy

Nr. 43/2015 Christine Clement, The Formal-Informal Economy Dualism in a Retrospective of Economic Thought since the 1940s

Nr. 44/2015 Niels Geiger, The Rise of Behavioural Economics: A Quantitative Assessment

Nr. 45/2015 Vadim Kufenko und Niels Geiger, Stylized Facts of the Business Cycle: Universal Phenomenon, or Institutionally Determined?

Nr. 46/2015 Niels Geiger und Vadim Kufenko, Business Cycles in the Economy and in Economics: An Econometric Analysis

Nr. 47/2015 Alex Arsenault Morin, Vincent Geloso und Vadim Kufenko, Infant Mortality and the Role of Seigneurial Tenure in Canada East, 1851

Nr. 48/2016 Vadim Kufenko, Spurious Periodicities in Cliometric Series: Simultaneous Testing

Nr. 49/2016 Vincent Geloso, Vadim Kufenko und Klaus Prettner, Demographic Change and Regional Convergence in Canada

Nr. 50/2016 Vincent Geloso, Vadim Kufenko und Remy Villeneuve, Living Standards in Lower Canada, 1831

Nr. 51/2016 Alex Arsenault Morin, Vincent Geloso und Vadim Kufenko, Monopsony and Industrial Development in Nineteenth Century Quebec: The Impact of Seigneurial Tenure 
Die Ursachen der gegenwärtig hohen Arbeitslosigkeit in einigen europäischen Ländern sind nicht allein in 'Funktionsproblemen des Arbeitsmarktes' zu suchen, sondern auch in Nachfrage- und Angebotsentwicklungen auf Güter- und Finanzmärkten. Im Promotionsschwerpunkt Globalisierung und Beschäftigung werden daher Dissertationsvorhaben gefördert, in denen die Beschäftigungseffekte gesamtwirtschaftlicher Entwicklungen untersucht werden - beispielsweise von neuen Technologien, von Prozessen der Internationalisierung und Systemtransformation, von marktseitigen Finanzierungsbeschränkungen oder von unterschiedlichen Strategien der Fiskal-, Geld- und Währungspolitik.

Die Betreuung und Vernetzung der Arbeiten im Promotionsschwerpunkt entspricht der Arbeitsweise eines Graduiertenkollegs. Betreuer des Schwerpunkts und Herausgeber der Schriftenreihe sind folgende Hochschullehrer:

Prof. Dr. Harald Hagemann

Institut für Volkswirtschaftslehre $(520 \mathrm{H})$

Universität Hohenheim

D-70593 Stuttgart

Prof. Dr. Heinz-Peter Spahn

Institut für Volkswirtschaftslehre (520A)

Universität Hohenheim

D-70593 Stuttgart

Prof. Dr. Hans-Michael Trautwein

Fakultät II - Institut für Volkswirtschaftslehre

Carl von Ossietzky Universität

D-26111 Oldenburg harald.hagemann@uni-hohenheim.de

peter.spahn@uni-hohenheim.de

michael.trautwein@uni-oldenburg.de

Dissertationsprojekte im Schwerpunkt können durch Promotionsstipendien des Evangelischen Studienwerks e.V. Villigst gefördert werden. Bewerbungsunterlagen können unter folgender Adresse angefordert werden:

Evangelisches Studienwerk e.V.

Promotionsförderung

Iserlohner Str. 25

58239 Schwerte

Tel.: 02304/755-215, Fax: 02304/755-250

Weitere Informationen zum Promotionsschwerpunkt sowie die Diskussionsbeiträge der Violetten Reihe im PDF-Format finden sich im Internet unter der Adresse:

http://www.globalization-and-employment.de 